\title{
КРИМІНАЛІСТИЧНА ХАРАКТЕРИСТИКА ПРЕДМЕТА ТА СПОСОБУ ВЧИНЕННЯ КОНТРАБАНДИ
}

Tитович H. B.

Стаття присвячена питанню криміналістичної характеристики предмета та способу вчинення контрабанди. Наголошено на тому, що дослідження елементів криміналістичної характеристики контрабанди має вагоме значення для організації ефективного процесу розслідування в практичній діяльності. Встановлено, що обмеження кола предметів контрабанди внаслідок внесення змін до Кримінального кодексу України в 2011 році вплинуло на процес розслідування. Доведено, що за допомогою предмета контрабанди можна розмежувати декілька складів злочинів, що закріплені в Кримінальному кодексі України, і контрабанду, що передбачена в Митному кодексі України. Проаналізовано загальний $і$ спеціальні склади злочинів у сфері контрабанди. Встановлено, що в практичній діяльності велике значення має доведення того, що конкретна річ належить до кола предметів контрабанди. Досліджено судову практику в контексті предмета та способу вчинення контрабанди. Аналіз судової практики показав, що найпоширенішим предметом контрабанди $\epsilon$ культурні цінності. Акцентовано увагу на тому, що в криміналістиці поняття способу вчинення злочину є ширшим, ніж у кримінальному праві. Встановлено, що в практичній діяльності трапляється широкий перелік способів вчинення контрабанди, які потребують своєчасного виявлення. Доведено, що доцільним є поділ способів контрабанди на дві групи - поза митним контролем та з приховуванням від митного контролю. За допомогою проведеного аналізу судової практики встановлено, що в практичній діяльності злочинці частіше використовують перший із зазначених способів. За допомогою аналізу праць науковців виявлено, що вони пропонують поділ способів вчинення контрабанди на особиcmi ma опосередковані. Наголошено на важливості визначення конкретного способу з огляду на необхідність доведення під час розслідування всіх ознак складу злочину, в тому числі і суб'єктивних, які передбачають встановлення вини в діях особи. Аналіз судових рішень показав, що обидва способи часто трапляються у практичній діяльності. Проілюстровано використання таких способів на конкретних прикладах із судових рішень.

Ключові слова: контрабанда, митний контроль, предмет контрабанди, криміналістика, склад злочину, товарна контрабанда.
Tytovych N. V. The criminalistic characterization of a subject and method of a smuggling

The article indicates the issue of the criminalistic characterization of a subject and method of a smuggling. It was emphasized that the research of elements of the criminalistic characterization of a smuggling is important for the organization of an effective investigation process in practice. It was established that the restriction of the range of contraband items due to amendments to the Criminal Code of Ukraine in 2011 affected the investigation process. It is proved that with the help of research of the subject of a smuggling it is possible to draw line between several types of crimes that codified in the Criminal Code of Ukraine and between a criminally punished smuggling and a smuggling that recognized in the Customs Code of Ukraine. The general and special structures of crimes in the field of smuggling are analyzed. It is established that in practice it is important to prove that a particular thing belongs to the range of contraband items. Judicial practice in the context of the subject and method of a smuggling is studied. Analysis of case law has shown that the most common subject of a smuggling is cultural values. It is emphasized that in criminalistics the concept of the method of committing a crime is broader than in criminal law. It is established that in practice there is a wide range of methods of a smuggling. It is important to detect such methods on time. It is proved that it is appropriate to divide smuggling methods into two main groups - out of customs control and with concealment from customs control. With the help of the analysis of judicial practice it is established that in practice perpetrators of a smuggling often use the first of these methods. By analyzing the works of scientists, it was found that they propose a division of methods of a smuggling into personal and indirect. The importance of determining a specific method is emphasized, given the need to prove during the investigation all the elements of the crime, including subjective ones, which involve establishing guilt of a person. Analysis of court decisions has shown that both methods are common in practice. The use of such methods is illustrated by specific examples from case law.

Key words: smuggling, customs control, contraband items, criminalistics, corpus delicti, illegal traffic.

(c) Титович Н. В., 2020 
Постановка проблеми та їі актуальність. Світова практика у сфері протидії злочинності свідчить про те, що контрабанда була і залишається поширеним злочином протягом тривалого часу. Саме тому дослідження особливостей іiі розслідування, зокрема питань криміналістичної характеристики, $\epsilon$ актуальним в умовах сьогодення. Необхідність детального вивчення цього питання зумовлена також тим, що в практичній діяльності постійно з'являються нові способи вчинення контрабанди, які потрібно своєчасно виявляти з метою запобігання злочинності.

Зміни до Кримінального кодексу Україні в 2011 році, що стосуються предмета контрабанди, суттєво вплинули на практичну діяльність ii розслідування, ефективність якого значною мірою залежить від стану теоретичного дослідження проблеми.

Невичерпність конкретних способів вчинення контрабанди призводить до ускладнення процесу виявлення та припинення таких злочинів. Моніторинг та узагальнення результатів практичної діяльності в частині предмета та способу вчинення контрабанди дасть можливість полегшити процес виявлення таких предметів та підвищити показники боротьби з контрабандою в Україні.

Аналіз останніх досліджень та публікацій. Вітчизняні та зарубіжні науковці досить часто присвячують свої праці розслідуванню контрабанди. Питання предмета та способу їі вчинення досліджували такі вчені та практичні працівники, як Р.С. Бєлкін, В.В. Варава, В.І. Волошин, О.П. Горох, А.Ф. Долженков, О.О. Дудоров, О.П. Дячкін, О.В. Карнаухов, П.Ю. Кравчук, А.А. Музика, А.С. Подшибякин, І.Л. Рудницький, О.І. Хараберюш, В.М. Шевчук, В.Ю. Шепітько та інші.

Однак, незважаючи на досить велику кількість праць, що повністю або частково присвячені досліджуваним питанням, у практичній діяльності постійно виникають нові способи вчинення контрабанди, які потребують безперервного моніторингу.

Метою цієї статті $\epsilon$ аналіз кримінально-правової та криміналістичної доктрини щодо питання криміналістичної характеристики предмета та способу вчинення контрабанди та встановлення найпоширеніших предметів та способів вчинення контрабанди за допомогою врахування результатів практичної діяльності.

Виклад основного матеріалу. Предмет та спосіб вчинення контрабанди $\epsilon$ обов'язковими елементами складу цього злочину і залишаються одними з головних елементів криміналістичної характеристики, незважаючи на внесення змін до КК України, оскільки мають велике значення для розмежування різних складів правопорушень, доведення наявності події злочину.

Предмет контрабанди, як елемент криміналістичної характеристики, має велике значення вже на початковому етапі розслідування, оскільки саме за критерієм предмета контрабанди проведено розмежування між кримінально караною контрабандою та контрабандою, що передбачена МК України. Крім того, предмет цього злочину дозволяє розмежувати його загальний склад, закріплений у ст. 201 КК України, від спеціальних (наприклад, від уже згадуваної ст. 305 КК України).

Як уже зазначалось, Законом № 4025-VI від 15 травня 2011 року виключено товари як предмет контрабанди. У зв'язку з цим до предмета контрабанди, склад злочину якої закріплено у статті 201 КК України, станом на 1 лютого 2021 року належать: 1) культурні цінності; 2) отруйні речовини; 3) сильнодіючі речовини; 4) вибухові речовини; 5) радіоактивні матеріали; 6) зброї або боєприпасів (крім гладкоствольної мисливської зброї або бойових припасів до неї); 7) частини вогнепальної нарізної зброї; 8) спеціальні технічні засоби негласного отримання інформації [1].

Контрабанда деяких предметів кваліфікується за спеціальними нормами, зокрема, наркотичних засобів, психотропних речовин, їх аналогів чи прекурсорів, фальсифікованих лікарських засобів - за ст. 305 КК України; лісоматеріалів або пиломатеріалів цінних та рідкісних порід дерев, лісоматеріалів необроблених, а також інших лісоматеріалів, заборонених до вивозу за межі митної території України, - за ст. 201-1 КК України [1].

Крім того, у статтях 199, 300 та 301 КК також встановлено відповідальність за перевезення, пересилання, ввезення в Україну з метою використання під час продажу товарів, збуту або збут підроблених грошей, державних цінних паперів, білетів державної лотереї, марок акцизного податку чи голографічних захисних елементів (ст.199 КК), за ввезення в Україну творів, що пропагують культ насильства і жорстокості, расову, національну чи релігійну нетерпимість та дискримінацію (ст.300 КК), за ввезення в Україну творів, зображень або інших предметів порнографічного характеру (ст. $301 \mathrm{KК).} \mathrm{Тобто} \mathrm{можна} \mathrm{погодитись}$ з думкою О.П. Дячкіна і зазначити, що вказаними нормами фактично передбачена відповідальність 

та науково-методичне забезпечення

за контрабанду, але яка полягає у лише ввезенні певних предметів в Україну і яку можна назвати імпортованою [2].

Зрозуміло, що в практичній діяльності велике значення має доказування того, що діяння було вчинене стосовно одного або декількох вищеперелічених предметів, оскільки це підтверджуватиме або спростовуватиме наявність у діяннях особи складу злочину. Однак не завжди можна встановити, чи належить конкретна річ до переліку предметів кримінально караної контрабанди.

Як доказ того, що було вчинено контрабанду конкретного предмета часто долучається висновок експертизи. Наприклад, вироком Центрально-Міського районного суду М. Кривого Рогу у справі № 216/4095/19 від 18 січня 2021 року ОСОБУ_1 було визнано винним у вчиненні, зокрема, кримінального правопорушення, передбаченого ч. 2 ст. 15 ч. 1 ст. 201 КК України. Як доказ того, що було вчинено саме замах на контрабанду спеціальних технічних засобів негласного отримання інформації органами досудового розслідування було надано висновок експерта Зонального експертного сектору ICTE СБ України в Управлінні СБ України у Дніпропетровській області № 6 від 17.01.2019, яким встановлено, що пристрій прямокутної форми приблизними розмірами 48*33*20 мм, чорного кольору, з лицьової сторони якого нанесений напис "PIR CALL ALARM" та знаходиться мініатюрний отвір діаметром приблизно $1 \mathrm{MM}$, пластикове віконце випукло-круглої форми білого кольору, кришка, під якою розташовується слот під «SIMкартку», роз’єм живлення типу “micro-usb” та інші два отвори належить до спеціальних технічних засобів негласного отримання інформації [3].

Проведене узагальнення вироків з Єдиного державного реєстру судових рішень у справах про контрабанду показало, що в практичній діяльності найпоширенішим предметом контрабанди $є$ культурні цінності. 350 проаналізованих вироків культурні цінності були предметом вчиненої контрабанди у 20 випадках.

У практичній діяльності такі предмети буває важко виявити, оскільки особи, які вчиняють контрабанду, вдаються до різних способів їх маскування або приховування. А тому зовні річ може виглядати як така, що не належить до предметів контрабанди. Тому зазвичай не $\epsilon$ достатнім проведення поверхневого огляду, а необхідна ретельність та уважність для того, щоб виявити такі предмети. Для цього необхідно мати обізнаність з приводу способів вчинення контрабанди, зокрема, найпоширеніших.
3 точки зору теорії кримінального права спосіб як ознака об'єктивної сторони злочину зазвичай визначається як форма прояву кримінально караного діяння, інакше кажучи, послідовність прийомів і методів, які використовує винний для вчинення умисного кримінального правопорушення (насильство, обман, зловживання довірою, використання безпорадного стану потерпілого тощо) [4, с. 180].

У криміналістиці використовується дещо інше поняття способу вчинення злочину - це детермінована система дій злочинця щодо підготовки, виконання та приховування незаконного переміщення контрабанди через митний кордон, а також щодо використання результатів контрабандної діяльності [5]. Це визначення $\epsilon$ дещо ширшим, оскільки включає прийоми, спрямовані на підготовку та приховання до злочинних дій.

У літературі виділяють найбільш типові способи вчинення контрабанди, до яких належать переміщення поза митним контролем та переміщення шляхом приховування від митного контролю [5].

На думку В.М. Шевчука, переміщення поза митним контролем передбачає ввезення або вивезення товарів та інших предметів через митний кордон України поза визначеними митними органами України місцями (митниці, митні пости) або поза встановленим часом для проведення митного контролю. Приховування від митного контролю предметів контрабанди являє собою будь-який спосіб утаювання, що ускладнює їх виявлення: із використанням тайників або інших засобів «фізичного приховування», які утруднюють візуальне виявлення контрабанди; шляхом надання одним предметам вигляду інших; шляхом подання митному органу як підстави для переміщення предметів підроблених документів або таких, що одержані незаконним шляхом, містять неправдиві дані чи $є$ підставою для переміщення інших предметів [6, с. 175].

Ці способи є загальновизнаними і визначаються шляхом тлумачення диспозиції ст. 201 КК України.

У Постанові Пленуму Верховного Суду України «Про судову практику у справах про контрабанду та порушення митних правил» від 03.06.2005 № 8 зазначено, що використанням інших засобів чи способів, що утруднюють виявлення предметів, можуть визнаватися, зокрема, приховування останніх у валізах, одязі, взутті, головному вбранні, речах особистого користування, на тілі або в організмі людини чи тварини, а також надання одним предметам вигляду інших (зміна їхніх зовнішніх ознак - форми та стану, упаковки, ярликів, етикеток тощо) [7]. 
Незважаючи на те, що вказана Постанова Пленуму ВС України $\epsilon$ дещо застарілою, оскільки ґрунтується на старих редакціях нормативно-правових актів, однак з точки зору розслідування контрабанди вказані способи залишаються поширеними, що підтверджується відповідною судовою практикою.

Такий спосіб приховування предметів контрабанди від митного контролю, як надання одним предметам вигляду інших, часто використовується у разі незаконного переміщення через кордон спеціальних технічних засобів негласного отримання інформації, що підтверджується відповідною судовою практикою. Наприклад, вироком Берегівського районного суду Закарпатської області у справі № 297/91/20 від 28 травня 2020 року ОСОБА_1 визнано винним у скоєнні злочину, передбаченого ч. 1 ст. 201 КК України, за таких обставин. ОСОБА_1, перебуваючи на території Угорщини, розмістив наявні у нього предмети, які мають функції запису відеота аудіо- у прихованій формі, а саме: 2 стакани з кришками; 3 блоки живлення; 1 роутер марки “MERCURY” з блоком живлення та диском; 7 авторучок; 14 USB-накопичувачів; 3 автомобільні ключі; 2 наручні годинники; 1 окуляри; 2 брелоки дистанційного керування; 1 мінікамеру з маркуванням MD-12; 1 мінікамеру для ведення прихованої зйомки в коробці з написом “CCD video camera"; 5 електронних настільних годинників; 1 ID-Card; 2 запальнички; 1 пристрій для USB-накопичувачів з написом на коробці “30W USB Power Adapter"; 2 настінні гачки (вішаки) для одягу; 2 адаптери з написами на коробках "Full HD Wifi Charger Camera A1"; 2 кабелі з антенами, камерами, блоками живлення та флеш-накопичувачами; 1 попільничку; 1 зарядний пристрій, у загальній кількості 54 предмети, у рюкзаку та сумці. При цьому з метою їх приховання ОСОБА_1 придбав продукти харчування та разом з особистими речами розмістив їх у рюкзаку та сумці, таким чином, щоб приховати вищевказані предмети [8].

Аналіз судових справ показав, що особи, які вчиняють контрабанду, на практиці використовують широкий перелік способів ії вчинення, які можна класифікувати на певні групи.

Особи можуть вчиняти контрабанду як особисто, так і за допомогою третіх осіб або організацій, які не обізнані з приводу предмета, який вони перевозять. Це зумовлює поділ способів вчинення контрабанди на особисті та опосередковані $[9$, с. 323].
Прикладом першого способу $є$ ситуація, що висвітлена у рішенні Дергачівського районного суду Харківської області у справі № 19/4700/20 від 22 грудня 2020 року. Вказаним вироком вказаного суду ОСОБА_1 визнано винним у вчиненні закінченого замаху на вчинення контрабанди боєприпасів, тобто їх переміщення через митний кордон України з приховуванням від митного контролю. ОСОБА_1 з метою унеможливлення виявлення під час здійснення митного контролю згортка та пакета з патронами помістив їх серед особистих речей у багажному відділенні належного йому автомобіля, де став надалі зберігати. Надалі ОСОБА_1 прибув на територію митного поста, де під час проведення усного декларування в ході митного контролю працівниками митниці не повідомив останніх про наявність заборонених (обмежених) до переміщення предметів і речей та намагався незаконно перемістити патрони через митний кордон України до Російської Федерації з приховуванням від митного контролю [10].

Як видно з фабули справи, ОСОБА_1 намагався особисто, з використанням власного транспортного засобу перемістити предмети контрабанди з приховуванням від митного контролю. У вказаній ситуацій також використано один з найпоширеніших способів приховування контрабанди - серед речей особистого користування.

Натомість вироком Херсонського міського суду Херсонської області у справі № 766/16192/20 від 23 грудня 2020 року ОСОБА_1 було визнано винуватим у вчиненні, зокрема, кримінального правопорушення, передбаченого ч. 2 ст. 15, ч. 1 ст. 201 КК України. ОСОБА_1, достовірно знаючи, що між Україною та Російською Федерацією встановлений митний кордон, у приміщенні поштового зв'язку Херсонської дирекції Акціонерного товариства «Укрпошта» надав працівникам поштового відділення зв' язку до пересилання міжнародне поштове відправлення на ім'я іншої особи у вигляді закле$\epsilon$ ної паперової коробки з прихованими усередині неї від митного контролю предметами: старовинними монетами у кількості 10 штук, старовинними наконечниками для стріл у кількості 10 штук, частинами вогнепальної зброї до пістолета-кулемета Шпагіна та револьверу Нагана, штик-ножем і тесаком [11].

У такому разі прослідковується спроба вчинення контрабанди другим способом із запропонованої класифікації, тобто шляхом використання необізнаності третіх осіб (у цьому разі працівників АT «Укрпошта»). 

та науково-методичне забезпечення

Наведена класифікація має значення для процесу розслідування, оскільки впливає на визначення суб'єктивних ознак складу злочину, що входять до предмета доказування. Зокрема, відсутність вини в діях особи виключатиме можливість притягнення до кримінальної відповідальності, а тому перед органами досудового розслідування стоїть завдання встановити наявність або відсутність суб' єктивних ознак складу злочину.

Висновки. Таким чином, дослідження предмета та способу як елементів криміналістичної характеристики контрабанди має вагоме теоретичне та практичне значення. Аналіз судових рішень у справах про контрабанду показує, що найпоширенішим предметом цього злочину $є$ культурні цінності. Як свідчить узагальнення результатів практичної діяльності, перелік конкретних способів вчинення контрабанди $\epsilon$ невичерпним. Однак аналіз показує, що особи переважно вчиняють контрабанду шляхом приховування від митного контролю, а не поза митним контролем.

\section{Література}

1. Кримінальний кодекс України : Закон України від 05.04.2001 № 2341-ІІІ. Відомості Верховної Ради України. 2001. № 25-26. Ст. 131.

2. Дячкін О.П. Суспільна небезпечність контрабанди і правова відповідальність за їі вчинення. Форум права. 2012. № 1. С. 281-288.

3. Вирок Центрально-Міського районного суду м. Кривого Рогу у справі № 216/4095/19. URL: https: / / reyestr.court.gov.ua/Review/94211476.

4. Кримінальне право : навчальний посібник. / О.О. Дудоров, М.І. Хавронюк ; за заг. ред. М.І. Хавронюка. Київ : Ваіте, 2014. 944 с.
5. Криміналістика : підручник / за заг. ред. В.Ю. Шепітька. 2-ге вид. Київ : Концерн «Видавничий Дім «Ін Юре», 2004. 728 с.

6. Криміналістика : підручник : у 2 т. / В.Ю. Шепітько, В.А. Журавель, В.О. Коновалова

та ін. ; за ред. В.Ю. Шепітька. Харків : Право, 2019. Т. 2, 328 c.

7. Постанова Пленуму Верховного Суду України «Про судову практику у справах про контрабанду та порушення митних правил» від 03.06.2005 № 8. URL: https://zakon.rada.gov.ua/laws/show/ v0008700-05\#Text.

8. Вирок Берегівського районного суду Закарпатської області у справі № 297/91/20 від 28 травня 2020 року. URL: https://reyestr.court.gov.ua/ Review/89631180.

9. Хараберюш О.І. Криміналістична характеристика злочинів та її значення для оперативно-розшукового забезпечення протидії контрабанді. Вісник Донецького національного університету. 2013. № 2. С. 322-326.

10. Вирок Дергачівського районного суду Харківської області у справі № 19/4700/20. URL: https: / / reyestr.court.gov.ua/Review/93729283.

11. Вирок Херсонського міського суду Херсонської області у справі № 766/16192/20. URL: https: / / reyestr.court.gov.ua/Review/93916753.

Tитович Н. В., студентка другого року навчання магістерської програми факультету правничих наук Національного університету «Києво-Могилянська академія» 